University for Business and Technology in Kosovo

UBT Knowledge Center

UBT International Conference

2014 UBT International Conference

Nov 8th, 12:00 PM - 12:15 PM

\title{
The process of euroisation and the economic development of the western Balkan Countries
}

Violeta Madzova

University Goce Delcev, violeta.madzova@ugd.edu.mk

Nehat Ramadini

University for Business and Technology, nehat.ramadani@ubt-uni.net

Follow this and additional works at: https://knowledgecenter.ubt-uni.net/conference

Part of the Business Commons

\section{Recommended Citation}

Madzova, Violeta and Ramadini, Nehat, "The process of euroisation and the economic development of the western Balkan Countries" (2014). UBT International Conference. 44.

https://knowledgecenter.ubt-uni.net/conference/2014/all-events/44

This Event is brought to you for free and open access by the Publication and Journals at UBT Knowledge Center. It has been accepted for inclusion in UBT International Conference by an authorized administrator of UBT Knowledge Center. For more information, please contact knowledge.center@ubt-uni.net. 


\title{
The process of euroisation and the economic development of the western Balkan Countries
}

\author{
${ }^{1}$ Violeta Madzova, ${ }^{2}$ Nehat Ramadani \\ ${ }^{1}$ University Goce Delcev -Faculty of Economics -Stip \\ ${ }^{2}$ Faculty of Management, Business and Economics \\ University for Bussiness and Technology -Prishtina, Kosova \\ violeta.madzova@ugd.edu.mk, nehat.ramadani@ubt-uni.net
}

\begin{abstract}
The trend of euroisation which started with the formal introduction of euro within Eurozone, was even extended over the countries from the Western Balkans, while two of them (Kosovo and Montenegro) have unilaterally introduced euro as the national currency without fulfilling Maastricht criteria. Other Balkans countries such as Serbia, Albania and Macedonia, were characterized with more or less extensive share of euro denominated deposits and loans in the banking sector balances.

At the beginning, the euroisation, brought positive movements in these countries especially to those ones who have low development and growth rate.

However, the sovereign debt crisis which severely "attacked" the euro zone countries, change the attitude of the monetary authorities, banks and private entities in the West Balkans countries to be more cautious regarding the extensive use of euro in their financial transactions, savings and credit activities. This paper aims to analyze the different levels of euroisation in different West Balkan countries and the impact which euroisation made on the level of their economic development, and financial stability.
\end{abstract}

Keywords: euroisation, economic development, macro-economic indicators.

\section{Introduction}

Being one of the most important economic integration today, European Union has introduced specific steps and rules for EU accession and formal adoption of the euro. However spontaneous confidence in the euro by citizens out of EU, including Balkan counties, was more than evident in the past ten years, which can be clearly illustrated by their currency behavior. Namely, in most countries of the Western Balkans, the bulk of bank deposits are denominated in euros, and euro is the most important foreign currency for the denomination of deposits, loans and liquid assets. More precisely, the euro banknotes in circulation for 2013 reached the value of 956 billion euro, out of which $20 \%-25 \%$ of the euro banknotes in circulation are held by people outside the euro area, in particular in the Western Balkans. Having in mind that the use of euro outside the euro area in 2003 was estimated to be worth $€ 36$ billion, accounting for around $10 \%$ of the total euro currency in circulation, it is easy to conclude the dramatic increase of the process of euroisaton over the past ten-years period.

\section{Euroisation- definition and forms}

Euroisation is voluntary, market forces driven use of the euro in the domestic monetary system alongside the national currency Although the EU legislation clearly defines the 3 steps way towards the adoption of the euro as a legal tender ( EU accession, undertaken procedures to participate in the "new" Exchange Rate mechanism and fulfilling Maastricht criteria), in practice, we have experienced different forms and levels of euroisation, which makes this phenomenon, more complex and challenging to analyze. 
Namely, besides the formal adoption of euro through the institutional process prescribed by EU, the theory and practice recognize: unofficial, unilateral and consensual euroisation ${ }^{37}$.

Unofficial euroisation denotes a phenomenon where economic agents voluntarily use the euro alongside the national currency. The spontaneous euroisation results from business concerns and is not a deliberate government policy of unilateral adoption of the euro.

Unilateral (and official) euroisation is the unilateral decision of a sovereign country to abandon its national currency partially or entirely in favor of adopting the euro as legal tender without joining EMU. In other words, unilateral euroisation means transition to the euro without having signed an appropriate agreement with the EMU member countries and the relevant EU institutions, nor fulfilling the nominal convergence criteria.

Consensual euroisation can be defined as an official introduction of the euro as legal tender, without respecting the institutional path of EMU, but resulting from an agreement between the euroising country and EU officials. Depending on the degree of cash substitution and the forms of euroisation substitution of assets and/or cash - euroisation is divided into moderate and extensive.

While moderate euroisation mainly means partial denomination of assets in the euro, extensive euroisation means the use of euro banknotes as well as extensive denomination of assets in euro. In extreme cases, the indexation of wages and prices can occur. As a rule, the indexation of wages and prices can only take place in a country where assets and banknotes have already been extensively substituted.

The motives of euroisation can differ, in different forms and types of euroisation. While moderate euroisation reflects the globalization of the world economy and integration of the markets, the reasons for extensive euroisation lie, first and foremost, in the instability of the economic policy of a concrete country or the internal or external imbalance of the economy. In the case of extensive euroisation or dollarisation the real sector is keeping its assets in foreign currency in order to reduce risks and foreign currency is circulating in the form of cash as well as account money.

The partial substitution of assets due to moderate euroisation facilitates the development of financial intermediation by creating additional ways to reduce the costs of international financial transactions, lowering market risks and diversifying asset portfolios. The latter is true mostly about the countries with less developed financial markets and limited opportunities of alternative risk covering options. As a part of Europe, the Balkans countries consider the adoption of the euro as an ultimate goal of both citizens and authorities, indicating that the adoption of euro is just a matter of time.

\subsection{What are the reasons for euroisation in Western Balkans countries?}

There are several reasons that motivate the Balkan countries towards extensive use of euro, among which the most important are the following:

Stronger economic and financial integration:

Euroisation is expected to improve a country's economic integration with the economy of the issuing country. This might be done through better trade integration, due to lower transaction costs and the elimination of exchange rate uncertainty, assuming that trade is fairly liberalized.

\section{Improved economic growth, development and stability}

As a consequence of higher economic integration, euroisation might lead to real convergence related to GDP levels and convergence of business cycles with the issuing country. In other words, a country with euroised economy might increase the economic growth and development of the economy, while economic shocks and business cycles might become more symmetric and more synchronized between the euroised country and the respective anchor country and assure better stability on long term.

Improving macroeconomic stability:

Euroisation is expected to foster macroeconomic stability by solving the credibility problem that arises when a domestic central bank is unable to pre-commit itself to a low rate of inflation. By explicitly

37 Eesti Pank,. 'Euroisation in Estonia and its impact on the economy', Kroon and Economy Publications, No. 1. (2002,pg 23-25) 
adopting the monetary policy of the issuing country, which enjoys a high degree of credibility, inflation and interest rates in the euroised economy are assumed to converge towards the level of the issuing country.

Lower risk premia:

If risk premia are owing to currency and not to country risk, euroisation should lead to lower risk premia, because a sharp and sudden devaluation of the domestic currency against the anchor currency is ruled out by definition. In particular, if a country is confronted with a currency mismatch (foreign currency borrowing by public or private sector entities without major foreign currency revenues), euroisation could eliminate this problem and therefore reduce the sovereign risk.

Domestic financial sector development:

Euroisation is expected to support the development of a country's financial sector, because a stable currency is a precondition for financial development, leading to strong and steady economic growth.

Elimination of transaction costs: The elimination of costs of exchanging the domestic currency into the currency of the anchor currency is the most visible effect of euroisation, with the cost savings being proportional to the number of transactions conducted in foreign currency.

\section{Euroisation in Western Balkans countries-state of art}

The above mentioned advantages and benefits were experienced also in the Western Balkans countries - most of them with EU candidate status. Namely, the trend of euroisation which was emphasized by the acceding EU countries in 2005 and $2007^{38}$, was even extended over the countries from the Western Balkans, while Montenegro and Kosovo have unilaterally introduced euro as their national currency. Bosnia and Herzegovina on the other hand, introduced so called convertible mark or BAM as it national currency in 1998, which is later on pegged to the euro. Since the euroisation in $\mathrm{BiH}$ presents very specific and unique case, additionally complicated with three level of authorities, in this paper, $\mathrm{BIH}$ will be excluded from the analysis on the correlation between euroisation and economic development of the euroised economies.

In other Balkans countries, the euroisation started slowly but was intensified during 2005-2009. Especially, Croatia which was on its way towards EU membership, (and become an EU member as of $1^{\text {st }}$ July 2013), registered high portion of FX assets and liabilities in the banks' balance sheets. In Macedonia for example, more than 50\% of banks loans and deposits were denominated or indexed in euro and in Serbia these figures were over 70\%. The banks in Albania at the same time kept $50 \%$ of their loans and deposits in euro.

At the beginning, the euroisation, in one form or another, brought positive trends of improvement related to GDP rate, rate of inflation, financial stability, foreign direct investments rate and economic and financial sector development especially to those Balkan countries with low development and growth rate, (such as Montenegro, Kosovo as well as Albania).

However the global financial and the debt crisis in Eurozone, brought new challenges for economic stability and development of the euroised Western Balkan economies and highlighted some side effects from the euroisation process.

The first effects of the financial crisis on the Western Balkans countries came with a significant lag and were generally not very significant until 2009 . The intensification of the eurozone crisis throughout 2011 and 2012 , has had a predictable impact on the Western Balkan economies. Already weakened by the effects of the global financial crisis on external trade, FDI inflows and remittances, they have been hit again by the renewed slowdown in the EU, which has exacerbated the economic volatility of the region. For example, Serbian real GDP fell by $1.7 \%$ in 2012 , heralding renewed recession at a time

\footnotetext{
38 In the mentioned period 17 new countries having a status of candidate countries, joined the EU, most of them without official introduction of the euro as national currency, but with moderate to extensive use of euro in deposit and credit activities of the banking sector.
} 
when unemployment is already above $25 \%$. Croatia, the newest member state of the EU, experienced its fourth year of recession in 2012 with a fall in real GDP of $2.0 \%$.

Therefore further bellow this paper will be analyzed several aspects and indicators which reflect economic development before the financial crises and during the sovereign debt crisis in Eurozone, first in two countries which officially and unilaterally adopted euro as their national currency (Montenegro and Kosovo), and then for the other Balkan countries with high level of euroisation .

\subsection{Euroisation versus economic development in the Balkans countries with unilateral official euroisation (Montenegro and Kosovo)}

As it was previously said unilateral and official euroisation means adoption of the euro as the only national currency, without having signed an appropriate agreement with the EMU member countries and the relevant EU institutions, nor fulfilling the nominal convergence criteria

In the case of Monenegro and Kosovo, European authorities were not involved in their euroisation process. Thus, there are no agreements between the European Union and Montenegro or Kosovo about the use of the euro as their official currency, moreover, there is no official link between the two countries' financial systems and the euro area.

\section{a. Montenegro}

In 2002, when Montenegro officially adopted the euro as domestic currency, it has one of the lowest level of GDP per capita in the Region, implying the annual amount of $€ 1,800$ per capita. Indeed, right after the introduction of euro, inflation rates declined rapidly, achieving the rate, close to euro area levels. These positive trends have been maintained till the beginning of the global financial crisis, when the inflation rate increased at the level of $9 \%$, followed by slow recovery period. The latest figures, however, indicates the acceptable inflation rates at the level of and 3\%, which is close to EU criteria. The beginning of sovereign debt crisis (2010) had extremely bad impact on the economy of Montenegro, reducing dramatically its GDP growth from positive growth of $10,7 \%$ in 2007, to negative one, ( $5,7 \%$ ) in 2009 . Although suffering with high rate of unemployment (which consistently increases year by year after the global crisis), the country managed to have slow but positive GDP growth, and in 2013 indicates GDP per capita of 11.900 \$, which is six times more than the level of the same indicator ten years ago. Although systemic risks appear to be manageable, there are pockets of vulnerability. The banking sector is exposed to macro-financial risks due to the openness of the economy, limited scope to diversify, and modest range of tools available to the authorities to promote macroeconomic stability.

\section{b. Kosovo}

The adoption of euro has brought to Kosovo the much-needed monetary stability by reducing inflation, eliminating the exchange rate risk which, in turn, helped reducing the transaction costs and promoting trade and investmentshas been very beneficial in bringing macroeconomic stability in the economy. Further, the euroisation in Kosovo implies the elimination of transaction costs with economic agents that also use euro but, of course, it does not eliminate transaction costs with those using other currencies. Moreover, the use of euro added with no exchange controls, allow Kosovar entrepreneurs to trade without being hampered by the burden of bureaucratic exchange control rules.

However, the low transaction costs generated by the use of euro are to be seen as an additional element to foster economic growth, but not as a key factor. High deficit of trade balance keeps being a great challenge for the economy of Kosovo. The high dependence of the Kosovo economy on the import of goods and the low level of exports led to persisting high trade deficit. As a onsequence of the global crisis impact, in 2009, both imports and exports declined, whereas the trade deficit marked a moderate annual growth. High import rates have and an impact on the trade deficit in 2009 which was at $€ 1.7$ billion (44.5 percent of GDP), while coverage of imports with exports was merely 8.6 percent.

Generaly, Kosovo's economy has shown significant progress in transitioning to a market-based system and maintaining macroeconomic stability, but it is still highly dependent on the international community and the diaspora for financial and technical assistance. Kosovo's citizens are the poorest in Europe with a per capita GDP of $\$ 7,600$ in 2013. Remittances from the diaspora - located mainly in Germany, 
Switzerland, and the Nordic countries - are estimated to account for about $15 \%$ of GDP, and donorfinanced activities and aid for approximately $10 \%$.

Although trade with the EU has increased, international trade is still concentrated on the neighboring non-euro countries. While currency risk has been eliminated, Kosovo has yet to fully utilize this benefit due to the luck of state status. Moreover, instead of reducing domestic interest rates, euroisation has not managed to lower the rates. As it is, Kosovo has the highest rates in the Balkans.

The loss of seigniorage revenues is immaterial in the case of Kosovo since Kosovo did not have its own currency prior to euroisation. The loss of independent monetary and exchange rate policy has been also important side effect. Inflation in Kosovo was quite fluctuating in recent years, being significantly influenced by price developments in the international markets. This is a result of the high degree of dependence of the country's economy on imported goods.

Analyzing the indicators such as annual GDP growth, FDI as \% in GDP and inflation rate as well as the export of goods and services as \% in GDP in both officially euroised economies and comparing the with same ones in the countries of Eurozone we can identify correlation between the indicators in euroised economies and the same ones in Eurozone indicated in Table 1.

Table 1 Montenegro and Kosovo versus Eurozone -economic indicators (2005-2013)

\begin{tabular}{llllllll}
\hline Indicators & $\mathbf{2 0 0 5}$ & $\mathbf{2 0 0 7}$ & $\mathbf{2 0 0 9}$ & $\mathbf{2 0 1 0}$ & $\mathbf{2 0 1 1}$ & $\mathbf{2 0 1 2}$ & $\mathbf{2 0 1 3}$ \\
\hline GDP growth in\% & & & & & & & \\
Montenegro & 4,2 & 10,7 & $-5,7$ & 2,5 & 3,2 & $-2,5$ & 3,5 \\
Kosovo & 2,0 & 8,3 & 3,0 & 3,2 & 4,5 & 2,7 & 3,0 \\
Eurozone & $\mathbf{2 , 2}$ & $\mathbf{2 , 9}$ & $\mathbf{- 4 , 4}$ & $\mathbf{2 , 0}$ & $\mathbf{1 , 6}$ & $\mathbf{- 0 , 7}$ & $\mathbf{- 0 , 4}$ \\
FDI as \% in GDP & & & & & & & \\
Montenegro & & 25,5 & 37,3 & 18,4 & 12,4 & 15,3 & 10,1 \\
Kosovo & 3,6 & 12,7 & 7,3 & 8,5 & 8,2 & 4,5 & 4,9 \\
Eurozone & $\mathbf{7 , 4}$ & $\mathbf{8 , 9}$ & $\mathbf{4 , 9}$ & $\mathbf{4 , 5 5}$ & $\mathbf{5 , 5}$ & $\mathbf{3 , 1}$ & $\mathbf{4 , 1}$ \\
Export of goods and servies as & $\mathbf{9}$ in GDP & & & & & \\
Montenegro & 47 & 44 & 32 & 35 & 43 & 44 & 44 \\
Kosovo & 15 & 16 & 17 & 20 & 20 & 18 & \\
Eurozone & $\mathbf{3 8}$ & $\mathbf{4 1 , 5}$ & $\mathbf{3 6 , 5}$ & $\mathbf{4 0 , 6}$ & $\mathbf{4 3 , 7}$ & $\mathbf{4 4 , 7}$ & $\mathbf{4 3 , 5}$ \\
Annual Inflation rate(\%) & & & & & & & \\
Montenegro & 3,4 & 4,2 & 3,4 & 0,5 & 3,1 & 2,0 & 4,0 \\
Kosovo & $-1,4$ & 4,4 & $-2,4$ & 3,5 & 3,4 & 2,5 & 1,8 \\
Eurozone & $\mathbf{2 , 2}$ & $\mathbf{2 , 2}$ & $\mathbf{0 , 3}$ & $\mathbf{1 , 6}$ & $\mathbf{2 , 7}$ & $\mathbf{2 , 5}$ & $\mathbf{1 , 4}$ \\
\hline
\end{tabular}

Source: The World Bank Data http://data.worldbank.org/indicator

When put in the trend line, each of these indicators suggested evident contribution of the euroisation to economic growth of the euroised countries, stabilization of inflation, intensifying export of goods and services and foreign direct investments. It is also notable that in the period of expansion economic indicators such as GDP annual growth rate and FDI as \% in GDP (Figure 1 and 2) have rapidly increased at the level higher than the same indicators in the Eurozone. 
Figure 1 GDP annual growth rate in \%- Figure 2: FDI as \% in GDP - Montenegro and Kosovo vs. Eurozone Montenegro and Kosovo vs. Eurozone
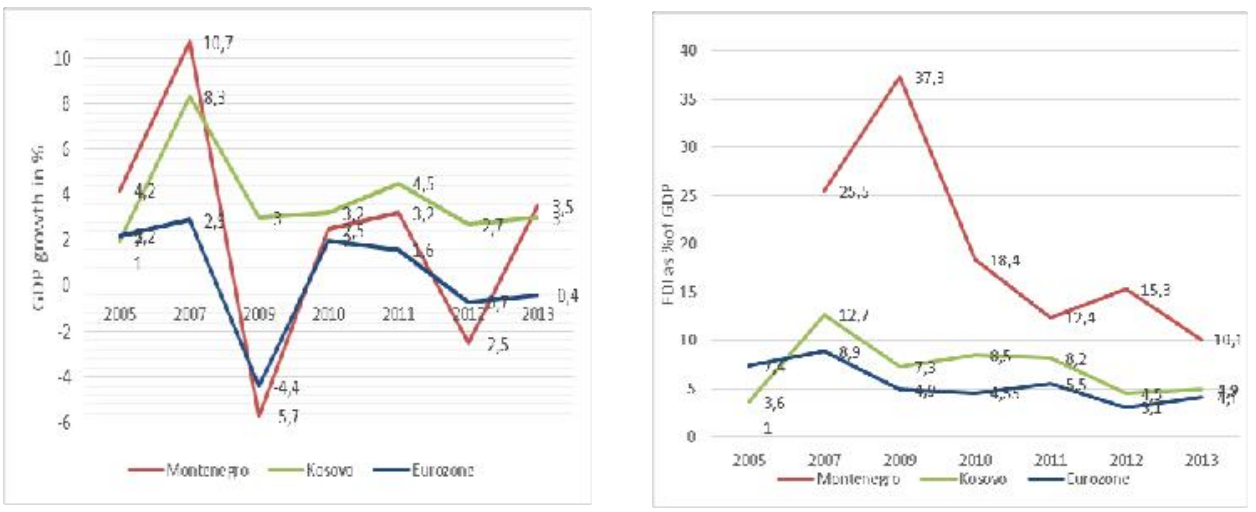

Source: Created by the author using The World Bank data

During the expansion, Montenegro as a country much more open for international trade than Kosovo, increased its export as \% of GDP at same level as the Eurozone countries, while Kosovo slightly increased its export reaching its pick, at the level of 20\% of GDP in 2011. (Figure 3). However in the period of crisis both countries have experience great economic shocks, experiencing turbulences with already stabilized inflation rate and even in worse way shared the destiny of the countries from Eurozone. (Figure 4)

Figure 3:Export of goods and servies as \% in

Figure 4 Annual inflation rateGDP-Montenegro and Kosovo vs. Eurozone

\section{Montenegro and Kosovo vs. Eurozone}
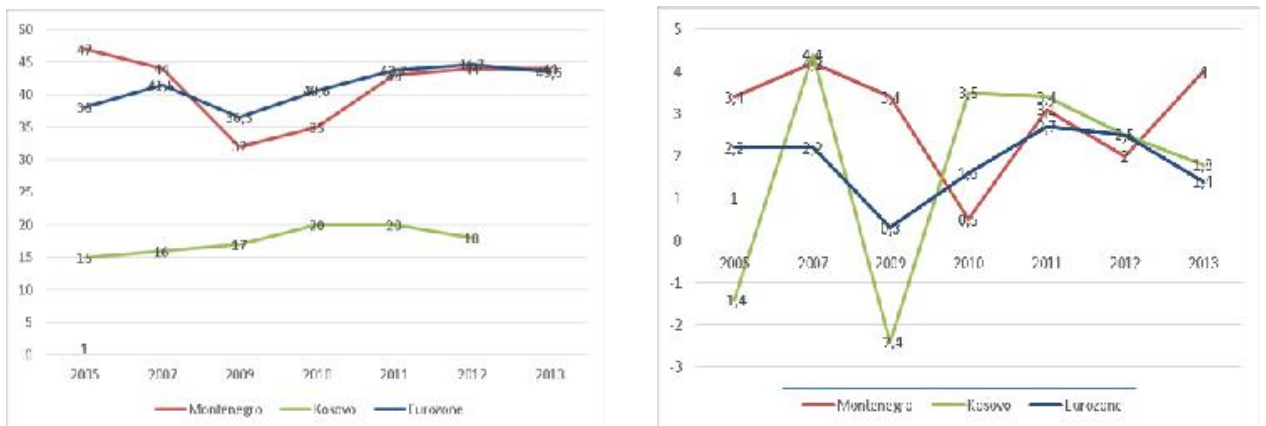

Source: Created by the author using The World Bank data

1.1. Euroisation versus economic development in the Balkans countries with unilateral official euroisation

Unofficial euroisation denotes a phenomenon where economic agents voluntarily use the euro alongside the national currency. The spontaneous euroisation results from business concerns and is not a deliberate government policy of unilateral adoption of the euro. The use of euro in the Western Balkan countries (besides those ones which officially adopted the euro), started right the official introduction of euro in the Eurozone. All of the Balkans countries: Albania, Croatia, Macedonia and Serbia progressively used the euro as cash or as legal tenner to express the value of their national currencies. The progressive use if euro was evident through increasing amount of deposits denominated in euro, as well as the loans that the banks have placed in non-banking sector which were denominated or indexed in euro as a tendency to protect themselves from the foreign exchange risk. As the American dollars has 
had pretty unstable foreign exchange rate, the stability of their euro was one of the most crucial factor, for the Balkans banks to hold large portion of their assets and liabilities in euro. However, the sovereign debt crisis which severely "attacked" the euro zone countries in 2009 and 2010 (with no prospects for soon recovery for some of them), change the attitude of the monetary authorities, banks and private entities in the West Balkans countries to be more cautious regarding the extensive use of euro in their financial transactions, savings and credit activities.

Namely, although these countries haven't introduced any official de-euroisation strategy, they have deployed some of the macro-prudent measures to moderate or even stop the trend of euroisation. As a result of these measures and the rumors about euro sustainability in Eurozone, the share of FX deposits has dropped more intensively at the liability side, while the loans indexed in euros were still at the high level in the bank's total assets. The most evident drop of euro denominated deposits and loans is registered in Macedonian banking sector, decreasing its deposit share from over $65 \%$ to $48 \%$, while the share of euro denominated and indexed loans marked decrease from over $70 \%$ to $45 \%$ at the end of 2013.The drop of FX deposits and loans is also evident in Croatia. The portion of over 70\% (for both euro denominated loans and deposits) was decreased at the level of $64 \%$ for loans and $58 \%$ for deposits in Croatian banking sector. The level of euroisation in Albania, measured with the $\%$ of euro deposits in total deposit varied from over $30 \%$ in 2005 to over 50\% in 2009 which was more or less kept till the end of 2013. The euroisation in Serbia supposed to bring macroeconomic stability and to moderate high inflation rate in the country. But, although Serbian banking sector faces with extensive euroisation, reaching portion of $73 \%$ FX indexed loams and $78 \%$ of FX deposits in total banks' deposits, the country is still experiencing high level of inflation and hasn't introduced any de-euroisation measures yet.

The issue whether euroisation contributes to higher economic performances in the euroised Balkans countries , can be discussed through analyzing the development of trend lines of the economic indicators in the four Western Balkans countries, comparing with the same ones in the countries in Eurozone as presented in the figures 5,6,7 and 8 .

It can be said that the two less developed and small economies (Albania and Macedonia) in the perod befor finacial crisis has achieved much bigger economic performances (GDP growth ).

Figure 5 GDP annual growth rate in \%Balkan countries vs. Eurozone

Figure $6:$ FDI as \% in GDP -

Balkan countries vs. Eurozone

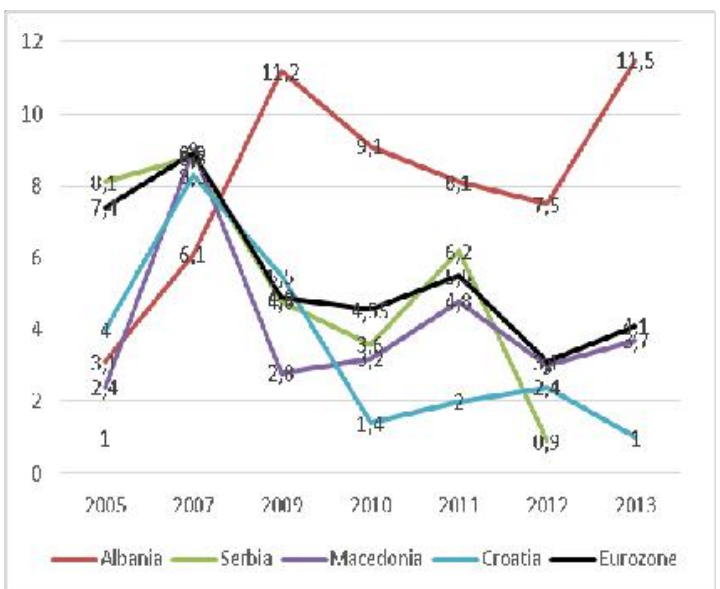

Source: Created by the author using The World Bank data

Regarding the GDP growth rate and FDI rate as \% of GDP it can be noticed that in all euroised Balkans countries, the trend line of these indicators follow the same shape as the one in Eurozone countries but with different amplitude. Yet, Albania as the least developed from all of these four countries, achieved the most favorable indicators, in both cases much better than those in Eurozone countries. In the same time, Croatia as the most wealthiest one, experienced an abrupt slowdown in the economy and acieved the lowest progress in both GDP and FDI growth. 


\section{Figure 7 Export of goods and services as \% $\quad$ Figure 8 Annual inflation rate in \% of GDP-Balkan countries vs. Eurozone \\ Balkan countries vs. Eurozone}

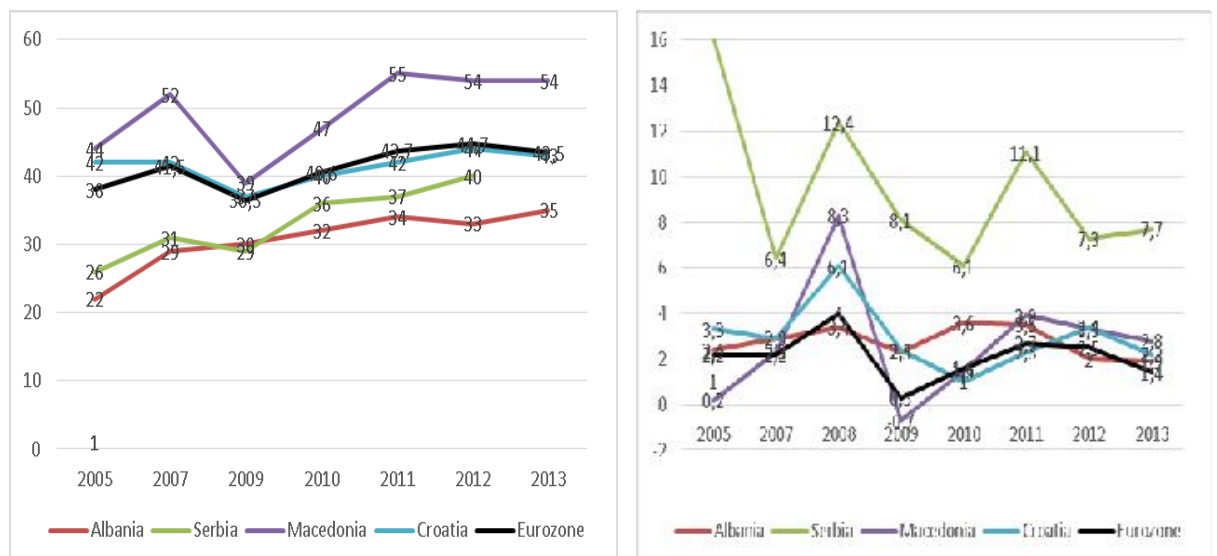

\section{Source: Created by the author using The World Bank data}

Economic indicator related to participation of the export in country's GDP is showing similar results. The countries with lower level of export of goods and services as \% of GDP ( such as Albania and Serbia) were not affected with turbulences of finacial and debt crisis in Eurozone and marked continously positive trend . Macedonia and Croatia, however with participation of export more than $40-50 \%$ of GDP, having strong trade relations with EU countries experienced ups and downs adequate to the economic situation of their trade partners. Regarding the inflation, it seems that euroisation helps serbian economy to decrease the extensive inflation rate at reasonable level, but during the crises paeriod , the country still experiences turbulances and inflatory shocks which were nit favorable for teh economy. The other counties felt the inflatory and deflatory trends the same way as the countriesin Eurozone, except Albania which has more moderate and less turbulent inflation rate overe the analyzed period.

Analyzing by countries we can make the follwing conlusions:

Albania has achieved strong positive economic growth over the recent years, despite the impact of the global financial and economic crisis. Although Albania managed to weather the first waves of the global financial crisis, recently, its negative effects have put some pressure on the Albanian economy. Being a significant catalyst for economic growth remittances declined from 12-15\% of GDP before the financial crisis to 7\% of GDP in 2013, mostly from Albanians residing in Greece and Italy. The country continue to face challenges from increasing public debt, having exceeded its former statutory limit of $60 \%$ of GDP in 2013. Strong trade, remittance, and banking sector ties with Greece and Italy make Albania vulnerable to spillover effects of debt crises and weak growth in the euro zone.

Though still one of the wealthiest Balkan countries with GDP per capita about 14.000 \$, Croatia experienced an abrupt slowdown in the economy during the funacial crisis and has yet to recover as the economic growth was stagnant or negative in each year since 2009. Difficult problems still remain, including a stubbornly high unemployment rate, uneven regional development, and a challenging investment climate. Croatia continues to face reduced foreign investment. Beeing a member of EU as of July 2013 Croatia felt pressure on the government to reduce its relatively high public debt, which triggered the EU's excessive deficit procedure for fiscal consolidation

Euroisation in Serbia is rooted in a long history of macroeconomic instability. Extreme inflation volatility has undermined trust in the dinar and discouraged dinar savings. At the same time, an abundant supply of foreign capital inflows has provided easy access to foreign currency lending at low interest 
rates in an environment of perceived exchange rate stability - a perception reinforced by the choice of exchange rate regime. As a result, both the asset and the liability side of banks' balance sheets, and even those of the non-bank sector, is heavily foreign currency-denominated. Serbia's high degree of euroisation raises policy challenges, both during tranquil times as well as during episodes of turbulence. Macedonia has made significant progress in liberalizing its economy and improving its business environment Although the rate of unemployment is still high, in recent years it has fallen by $10 \%$ reacing the rate below $30 \%$. Macedonia's economy is closely linked to Europe as a customer for exports and source of investment, and has suffered as a result of prolonged weakness in the euro zone. Macedonia maintained macroeconomic stability through the global financial crisis by conducting prudent monetary policy, which keeps the domestic currency pegged against the euro, and by limiting fiscal deficits. The government has been loosening fiscal policy, however, and the budget deficit expanded to $4.2 \%$ of GDP in 2013. Macedonia achieved modest GDP growth in 2013 after a small contraction in 2012, while the inflation has been kept under control all over the crisis period.

\section{Conclusions}

Partial substitution of assets that results from the euroisation, facilitates the development of financial intermediation, by allowing further reduction of the costs of international financial transactions, lowering of market risks and diversification of asset portfolios. Euroisation helps especially the countries with low level of economic development to accelerate their economic growth rate, increase their export of goods and services, stimulate inflow of FDI as well as to stabilize the inflatory turbulences. However the excessive euroisation in the country while official currency exist decrease the power of instruments of the monetary authority to fight with financial stability and overdebtness of the country, which turns to be the biggest problem within Eurozone area during the financial crisis. The countries that have extensive euroisation in the banking balance sheets or even unilaterally introduced euro have at first stage might experience the high level of GDP growth, but during the crisis period they share the problems from Eurozone, more evidently than the other countries

\section{References}

1) Eesti Pank,. 'Euroisation in Estonia and its impact on the economy', Kroon and Economy Publications, No. 1. (2002)

2) Sandrine Levasseur "Why not Euroisation" Economist at the OFCE Economic Research Department, Special issue, April 2004

3) Glick, R. and Rose, A. (2002). 'Does a Currency Union Affect Trade ?The Time-Series Evidence', European Economic Review, 46(6),pp. 1125-1151.

4) Central Bank of Montenegro (2003-2012 ): “Chief Economist's Reports, , http://www.cbmn.org/indexE.htm.

5) Gligorov, V. (2001): "The Euro in the Balkans", The Vienna Institute for International Economic Studies, http://www.eu-enlargement.org/discuss/attachments/B7CE25FF4EAA-11D5-A2F6-0050DA76D265.DOC

6) Roland Back at all "Financial stability challenges for EU acceding and candidate countries "Occasional paper series, No 136, Sept. 2012.

7) Maloku E., Badivuku M.,"How Acceptable are the Costs Compare to Benefits Brought by Euroisation of Kosovar Economy", www.scientificpapers.org.,

8) http://ec.europa.eu/economy_finance/publications/publication15155_en.pdf5 
9) http://www.bankofalbania.org/web/Annual_Report_2013_6609_2.php?ks 